\title{
Elemental analysis of aerosol organic nitrates with electron ionization high-resolution mass spectrometry
}

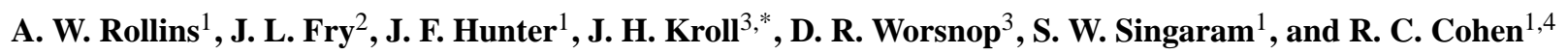 \\ ${ }^{1}$ Department of Chemistry, University of California Berkeley, Berkeley, CA 94721, USA \\ ${ }^{2}$ Chemistry Department, Reed College, Portland, OR 97202, USA \\ ${ }^{3}$ Aerosol and Cloud Chemistry, Aerodyne Research Inc., Billerica, MA 01821, USA \\ ${ }^{4}$ Department of Earth and Planetary Science, University of California Berkeley, Berkeley, CA 94721, USA \\ *now at: Department of Civil and Environmental Engineering, Massachusetts Institute of Technology, Cambridge, \\ MA 02139, USA
}

Received: 5 August 2009 - Published in Atmos. Meas. Tech. Discuss.: 30 October 2009

Revised: 17 February 2010 - Accepted: 18 February 2010 - Published: 26 February 2010

\begin{abstract}
Four hydroxynitrates $\left(\mathrm{R}(\mathrm{OH}) \mathrm{R}^{\prime} \mathrm{ONO}_{2}\right)$ representative of atmospheric volatile organic compound (VOC) oxidation products were synthesized, nebulized and sampled into an Aerodyne High Resolution Time of Flight Aerosol Mass Spectrometer (HR-ToF-AMS). The resulting mass spectrum was used to evaluate calibration factors for elemental analysis of organic nitrates by AMS, and to determine the distribution of nitrogen in the detected fragments in a search for an AMS signature of organic nitrates. We found that $30 \%$ of the detected nitrogen mass is in the $\mathrm{NO}^{+}$and $\mathrm{NO}_{2}^{+}$fragments, $12 \%$ at $\mathrm{NH}_{\mathrm{x}}^{+}$fragments, $5 \%$ at $\mathrm{C}_{\mathrm{x}} \mathrm{H}_{\mathrm{y}} \mathrm{O}_{\mathrm{z}} \mathrm{N}^{+}$ fragments, and $53 \%$ at various $\mathrm{C}_{\mathrm{x}} \mathrm{H}_{\mathrm{y}} \mathrm{N}^{+}$fragments. Elemental analysis indicated that nitrogen was detected with higher efficiency than carbon and hydrogen, but oxygen was detected with reduced efficiency compared to previously reported results for a suite of organics which did not include organic nitrates. The results are used to suggest the maximum corrections to ambient $\mathrm{O}: \mathrm{C}$ and $\mathrm{N}: \mathrm{C}$ ratios based on AMS measurements.
\end{abstract}

\section{Introduction}

Aerosol mass spectrometry is a widely used method for measuring atmospheric aerosol composition. The most common implementation of this class of instruments is the Aerodyne Aerosol Mass Spectrometer (AMS) of which more than 80 instruments are currently in operation worldwide. Due to

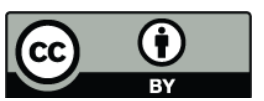

Correspondence to: R. C. Cohen (cohen@cchem.berkeley.edu) its ubiquitous use in laboratory and field experiments, much of what is known about ambient atmospheric and laboratory aerosol composition relies on the accurate interpretation of AMS data. One of the main advantages of the AMS is it's combination of flash volatilization with electron impact (EI) ionization which results in a relatively uniform sensitivity to all non-refractory (NR) components of aerosols, allowing for a measurement of total particle mass with high time resolution and without requiring detailed prior knowledge of the aerosol chemical composition (Jimenez et al., 2003).

AMS spectra of ambient aerosol consists of a complex set of fragments with the majority of the mass typically detected as fragments with mass/charge ratios $(\mathrm{m} / \mathrm{z})$ less than 100 due to the high degree of fragmentation induced by flash volatilization and electron impact. The increased internal energy of the vapors due to the flash volatilization is known to increase the degree of fragmentation relative to molecules at standard temperature (Alfarra, 2004; Dzepina et al., 2007) and thermally unstable molecules such as ammonium nitrate are known to decompose prior to ionization. Due to the molecular fragmentation of the sampled particles, chemical speciation is typically limited to the identification of compounds with signature $m / z$ (i.e. sulfate, nitrate, ammonium, chloride) and an assumption that the majority of the unidentified mass is organic (Allan et al., 2004). Positive matrix factorization has been applied to the resulting organic spectra (Zhang et al., 2005; Lanz et al., 2007, 2008) revealing unique components of the spectra which are indicative of e.g. more or less oxidized molecules. Generally, oxygen content of the aerosol is observed to increase with the photochemical age of a plume and this trend has been shown to be consistent with other measures of organic mass:organic carbon.

Published by Copernicus Publications on behalf of the European Geosciences Union. 
Organic nitrates $\left(\mathrm{R}-\mathrm{O}-\mathrm{NO}_{2}\right)$ are ubiquitous in the atmosphere and are generated both from photochemical oxidation of VOC's in the presence of NO, as well as through oxidation of alkenes by nitrate radicals $\left(\mathrm{NO}_{3}\right)$. In particular, hydroxy nitrates ( $\beta$ and $\delta$ isomers) are the dominant organic nitrate oxidation product of alkenes including isoprene and monoterpenes (e.g. Noziére et al., 1999, Paulot et al., 2009). The addition of nitrate and alcohol groups have similar effects on the vapor pressure, and hence condensibility of an organic compound (Pankow and Asher, 2008; Kroll and Seinfeld, 2008). As a result, oxidation of biogenic VOC's (BVOC) by $\mathrm{NO}_{3}$ has been observed to produce aerosol with significant yields in chamber studies (e.g. Hoffmann et al., 1997; $\mathrm{Ng}$ et al., 2008; Fry et al., 2009; Rollins et al., 2009). Organic nitrates might be expected to play an important role in production of Secondary Organic Aerosols (SOA) because of the correlation between $\mathrm{NO}_{\mathrm{x}}$ and anthropogenic VOC emissions, because $\mathrm{NO}_{3}$ is an effective means for oxidizing BVOC, and because $\mathrm{RONO}_{2}$ are produced in high $\left(\approx 25 \%\right.$ ) yield in the $\mathrm{RO}_{2}+\mathrm{NO}$ reaction for $\mathrm{R}>\mathrm{C}_{8}$ (Arey et al., 2001). However, identification of organic nitrates in ambient aerosol is difficult because it is expected to occur in coincidence with a large amount of inorganic nitrate. In AMS instruments the $\mathrm{NO}_{3}^{-}$results in a large background signal at the main nitrate peaks $\left(\mathrm{NO}^{+}\right.$and $\left.\mathrm{NO}_{2}^{+}\right)$. Organic nitrates could in principle be determined by subtraction of the inorganic contribution at these peaks which is calculated assuming an ion balance between ammonium, sulfate and nitrate, and other minor inorganic components if present in the aerosol. This is difficult and a direct organic signature would be desirable.

Recently, the high resolution version of the AMS (HRToF-MS) has been used to determine elemental composition of organic aerosol (Aiken et al., 2007, 2008). While the AMS is to first order equally sensitive to all NR aerosol (Jimenez et al., 2003), it is known to detect oxygen and nitrogen with somewhat reduced efficiency relative to carbon and hydrogen. Aiken et al. (2008) used a series of organic standards to determine calibrations for the calculation of $\mathrm{O} / \mathrm{C}$, $\mathrm{H} / \mathrm{C}$ and N/C ratios from AMS data. This is possible with the HR-ToF-AMS because of its ability to distinguish different fragments with the same nominal mass, and compare the measured composition to the composition of the standards. These experiments did not include any organic nitrates because semi-volatile organic nitrates were not commercially available. Other nitrogen containing organic compounds were tested including amine, amide nitro and pyradine compounds. In contrast to these species organic nitrates are relatively thermally unstable and are known to decompose at $300-400^{\circ} \mathrm{C}$ in 10 's of $\mathrm{ms}$ the gas phase at atmospheric pressure (Day et al., 2002). Thus their detection could be more significantly affected by the combination of flash volatilization/EI than these other nitrogen containing organics.<smiles>C=C(C)C1CCC(C)(O[N+](=O)[O-])C(O)C1</smiles>

2-hydroxy-limonene-1-nitrate<smiles>CC1(C)C2CC(O)C1(C)C([O+]([O-])O[N+](=O)[O-])C2</smiles>

3-hydroxy-pinene-2-nitrate

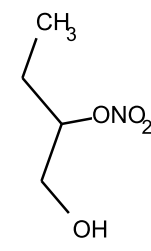

1-hydroxy-butane-2-nitrate

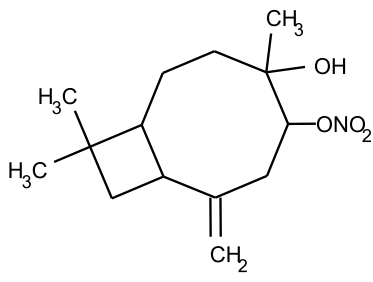

3-hydroxy-caryophyllene-4-nitrate
Fig. 1. One isomer of each each standard synthesized for this study.

We have synthesized 4 organic nitrates $\left(\mathrm{C}_{4}-\mathrm{C}_{15}\right)$ and investigated the response of the AMS to these compounds. The molecules used here were all hydroxynitrates and were chosen for their similarity to known oxidation products of atmospheric VOC's. Hydroxynitrates with e.g. isoprene and monoterpene carbon backbones have been observed in ambient aerosols (Surratt et al., 2006; Gómez-González et al., 2008) making the molecules used in this study representative of organic nitrates believed to be in ambient aerosols. High resolution spectra were used to determine calibrations for elemental analysis based on these compounds. The differences between elemental analysis calibrations for organic nitrates and for the suite of compounds and ambient sample investigated by Aiken et al. (2008) and differences between AMS spectra of inorganic and organic nitrates are discussed.

\section{Experimental}

Four hydroxynitrate compounds including 2-hydroxylimonene-1-nitrate, 1-hydroxy-butane-2-nitrate, 3-hydroxypinene-2-nitrate, and 3-hydroxy-caryophyllene-4-nitrate (and regioisomers) were synthesized by reacting an epoxide with fuming nitric acid (90\%). Previous studies describing hydroxynitrate synthesis and characterization using this and other synthetic methods include Nichols et al. (1953), Muthuramu et al. (1993), Treves et al. (2000), Spittler (2001) and Treves and Rudich (2003). The synthesis generated a mixture of regioisomers, and in Fig. 1 we show one isomer of each standard. In the following we describe the synthesis of the limonene hydroxynitrate. The other three compounds were prepared analogously. 
Table 1. H/C, N/C and O/C data from combustion elemental analysis and AMS elemental analysis.

\begin{tabular}{lrrrr}
\hline Compound name & Butane & Pinene & Limonene & Caryophyllene \\
\hline Compound formula & $\mathrm{C}_{4} \mathrm{H}_{9} \mathrm{O}_{4} \mathrm{~N}$ & $\mathrm{C}_{10} \mathrm{H}_{17} \mathrm{O}_{4} \mathrm{~N}$ & $\mathrm{C}_{10} \mathrm{H}_{17} \mathrm{O}_{4} \mathrm{~N}$ & $\mathrm{C}_{15} \mathrm{H}_{25} \mathrm{O}_{4} \mathrm{~N}$ \\
Atomic H:C & 2.25 & 1.70 & 1.70 & 1.67 \\
Atomic N:C & 0.25 & 0.10 & 0.10 & 0.067 \\
Atomic O:C & 1 & 0.4 & 0.4 & 0.27 \\
Combustion H:C & 2.32 & 1.54 & 1.79 & 1.69 \\
Combustion N:C & 0.22 & 0.057 & 0.071 & 0.013 \\
Combustion O:C & 0.97 & 0.25 & 0.26 & 0.11 \\
AMS H:C & 2.2 & 1.5 & 1.7 & 1.6 \\
AMS N:C & 0.33 & 0.041 & 0.099 & 0.022 \\
AMS O:C & 0.29 & 0.12 & 0.12 & 0.086 \\
AMS O:C/combustion O:C & 0.20 & 0.46 & 0.46 & 0.79 \\
\hline
\end{tabular}

\subsection{Synthesis}

To a flame dried $25 \mathrm{~mL}$ round bottom flask equipped with a stir bar was added $6.52 \mathrm{mmols}(1.07 \mathrm{~mL})$ of limonene-1,2oxide (mixture of cis and trans, 97\%, sigma-aldrich) and dissolved in $8 \mathrm{~mL}$ of dry diethyl ether (starting materials for the other standards were $\alpha$-Pinene oxide (97\%), 1,2Epoxybutane (99\%) and Caryophyllene oxide ( $>95 \%$ ) all of which were obtained from Sigma-Aldrich). To another flame dried $25 \mathrm{~mL}$ round bottom flask equipped with a stir bar was added $3 \mathrm{~mL}$ of dry diethyl ether and $7.39 \mathrm{mmols}(0.3 \mathrm{~mL})$ of fuming nitric acid. These flasks were placed, under nitrogen, in a dewar and cooled to $-90^{\circ} \mathrm{C}$ via a methanol/acetone bath in a CryoCool immersion cooler. After cannulating the acid into the epoxide, the solution was kept at $-90^{\circ} \mathrm{C}$ for an additional hour. The reaction flask was then allowed to warm to room temperature over $12 \mathrm{~h}$. The solution was washed several times with sodium bicarbonate to remove excess $\mathrm{HNO}_{3}$ and then dried over magnesium sulfate. The ether layer was removed with a rotatory evaporator. The product was purified on a silica gel column with a 60/40 mixture of hexanes/ethyl acetate. A diffusion pump was finally used to remove any moderately volatile products from the standards by applying vacuum to $\sim 5$ mTorr for one hour.

\subsection{Characterization of standards}

A $400 \mathrm{MHz}$ NMR spectrometer was used to obtain ${ }^{1} \mathrm{H}$ NMR and ${ }^{13} \mathrm{C}$ NMR spectra. The observed chemical shifts for the limonene hydroxynitrate dissolved in $\mathrm{CDCl}_{3}$ are as follows:

- ${ }^{1}$ HNMR: $1.45(2, \mathrm{~m}) ; 1.6(3, \mathrm{~s}) ; 1.7(3, \mathrm{~s}) ; 1.80(2, \mathrm{~m})$; $2.18(2, \mathrm{~m}) ; 2.35(1, \mathrm{~m}) ; 4.09(1, \mathrm{~m}) ; 4.73(2, \mathrm{~m})$,

- ${ }^{13}$ CNMR: 20.78; 20.83; 26.05; 29.88; 33.80; 36.78; $69.1 ; 91.45 ; 109.35 ; 148.43$.

Our NMR observations are in agreement with those of Spittler (2001).
Thermal dissociation-laser induced fluorescence (Day et al., 2002) measurements of the vapors in the headspace in each sample vial unambiguously identified the standards as being composed of alkyl nitrates. $\mathrm{HNO}_{3}, \mathrm{NO}_{2}$ and $\mathrm{RO}_{2} \mathrm{NO}_{2}$ compounds were not detected in the vapors.

Samples were analyzed for elemental composition using a standard combustion method (Perkin Elmer 2400 Series II). With this method, carbon, hydrogen and nitrogen content were measured on a mass basis with a stated accuracy of $\pm 0.3 \%$. Oxygen was assumed to be the remaining mass such that $\mathrm{C}+\mathrm{H}+\mathrm{O}+\mathrm{N}=100 \%$. Results of the combustion analysis are listed in Table 1.

\subsection{HR-ToF-AMS analysis}

The AMS has been extensively described in the literature (Canagartna et al., 2007; DeCarlo et al., 2006) and is only briefly described here. The AMS exists in three basic implementations. These instruments all sample gas and particles through an aerodynamic inlet which reduces the sampled gas relative to the particles by a factor of $\approx 10^{7}$. The resulting focused beam of particles with aerodynamic diameters $\approx 30-1000 \mathrm{~nm}$ is impacted on a heated surface $\left(\approx 600^{\circ} \mathrm{C}\right)$ where the non-refractory component of the aerosol is vaporized. The resulting vapors are ionized with $70 \mathrm{eV}$ electron impact and measured with mass spectrometry. The three versions of the AMS differ primarily in the mass spectrometer used, which has evolved from quadrupole (Q-AMS) to time of flight (ToF-AMS) to high resolution time of flight (HRToF-AMS). The ToF-AMS has much higher precision than the Q-AMS because it is not a scanning instrument and therefore can in principle collect all of the $\mathrm{m} / \mathrm{z}$ fragments from a single particle. HR-ToF-AMS has improved mass resolution, allowing for the distinction between different fragments with the same nominal mass (e.g. $\mathrm{CH}_{2} \mathrm{O}^{+}$vs. $\mathrm{NO}^{+}$).

For these experiments the higher resolution $\mathrm{W}$ mode of a HR-ToF-MS was used. Data was collected from $m / z=10$ to $m / z=500$. The data was analyzed using Igor Pro 6.04 
(Wavemetrics, Lake Oswego, OR) which runs the standard HR-ToF-AMS software packages Squirrel 1.43 (ToF-AMS), Pika 1.03 (HR-ToF-AMS module) and Apes 1.00 (organic aerosol elemental analysis module).

Performing EA using the HR-ToF-AMS has been described in the literature (Aiken et al., 2007, 2008) and is briefly described in this paper. This analysis relies on the principle that a given magnitude of signal $(\mathrm{Hz})$ at any $\mathrm{m} / \mathrm{z}$ corresponds roughly to the same original mass in the EI region of the instrument. For example, $1 \mu \mathrm{g} / \mathrm{m}^{3} \mathrm{He}$ and $1 \mu \mathrm{g} / \mathrm{m}^{3} \mathrm{Ar}$ would produce approximately equal signal count rates at $m / z=4\left(\mathrm{He}^{+}\right)$and $40\left(\mathrm{Ar}^{+}\right)$, even though the number of $\mathrm{Ar}$ atoms relative to $\mathrm{He}$ is $1 / 10$. Furthermore, for molecules which fragment upon ionization, the size and identity of the fragment which retains the charge and is detected has no bearing on the size of the signal. This is because the detection efficiency is proportional to the probability of a molecule becoming ionized, which is to first order linear in the number of electrons and therefore the mass of the molecule (Jimenez et al., 2003). Regardless of the size of the fragment that leaves as charged, the resulting signal from one ionizing event is 1 count (scaled by the detection efficiency of the instrument). Since the HR-ToF-AMS can determine the elemental composition of individual fragments by distinguishing between different fragments with the same nominal mass (DeCarlo et al., 2006), an average elemental composition and atomic ratios can be calculated for the entire HR-ToF-AMS spectrum. Calculating the average elemental composition of just the organic part of the aerosol requires determining which fragments and also how much of the total signal at each fragment comes from the organic part of the aerosol. For ambient aerosol this can be difficult since inorganic aerosol and air may overlap at important $\mathrm{m} / \mathrm{z}$ for particular types of compounds. As a pair of examples, $\mathrm{H}_{2} \mathrm{O}^{+}$ may come from both water vapor and the alcohol functional group, while $\mathrm{NO}^{+}$may appear due to either ammonium nitrate or organic nitrate molecules.

As discussed by Aiken et al. $(2007,2008)$ the contribution to the organic spectrum from the $\mathrm{CO}^{+}, \mathrm{O}^{+}, \mathrm{OH}^{+}$and $\mathrm{H}_{2} \mathrm{O}^{+}$ fragments cannot typically be measured directly by the AMS when sampling particles in air due to inorganic gas phase and particle phase interferences. The signal from the gas phase interferences is measured by intermittently blocking the particle beam, resulting in a gas only signal which is then subtracted from the gas + particle signal measured with the beam not blocked. The result will be precise however only if the gas is a small fraction of the total signal. $\mathrm{CO}_{2}$ is one gas for example for which this could be expected to be an issue. $380 \mathrm{ppm} \mathrm{CO} 2$ at standard conditions is $\approx 7 \times 10^{5} \mu \mathrm{g} / \mathrm{m}^{3}$. Applying the nominal particle:gas enhancement factor of $10^{7}$ to this results in a signal of $\approx 0.07 \mu \mathrm{g} / \mathrm{m}^{3}$ from gas phase $\mathrm{CO}_{2}$ which is a background signal over which the particle signal must be measured. For ambient organic aerosols on the order of $10 \mu \mathrm{g} / \mathrm{m}^{3}$ where the $\mathrm{CO}_{2}$ is typically on the order of 10 $20 \%$ of the total organic aerosol signal (Zhang et al., 2005;
Aiken et al., 2008) gas phase $\mathrm{CO}_{2}$ is a minor interference. However, for less oxidized aerosols such as standards and chamber SOA, it can be significant because these aerosols produce very little $\mathrm{CO}_{2}^{+}$signal. We found for example with our pinene hydroxynitrate standard that with $150 \mu \mathrm{g} / \mathrm{m}^{3}$ organic aerosol concentration, the gas and particle signals at $\mathrm{CO}_{2}^{+}$were $\approx 4: 5$, particle:gas. However, the reduction in the precision of the $\mathrm{CO}_{2}^{+}$fragment measurement for less oxidized aerosols has a small impact on the precision of the calculated $\mathrm{O} / \mathrm{C}$ because as the noise in the particle $\mathrm{CO}_{2}^{+}$signal increases, the fraction of total particle mass from this fragment decreases. A similar analysis on water vapor at $50 \%$ $\mathrm{RH}$ and standard conditions results in a gas phase signal of $1.2 \mu \mathrm{g} / \mathrm{m}^{3} \mathrm{H}_{2} \mathrm{O}$, which is always a significant interference, even if gas phase water is reduced with a diffusion dryer. In our measured spectra of the butane hydroxynitrate we found that the expected $\mathrm{H}_{2} \mathrm{O}^{+}$organic aerosol signal one calculates from the measured $\mathrm{CO}_{2}^{+}$and the fragmentation suggested by Aiken et al. (2008) is $0.04 \%$ of the total measured $\mathrm{H}_{2} \mathrm{O}^{+}$ signal, making a determination of $\mathrm{H}_{\mathrm{x}} \mathrm{O}^{+}$fragments from difference spectra impossible. The large $\mathrm{N}_{2}^{+}$peak from air in these experiments was typically $\approx 100$ times larger than the adjacent $\mathrm{CO}^{+}$fragment which itself is due both to gas phase $\mathrm{CO}_{2}$ as well as $\mathrm{CO}^{+}$fragments from organic particles. For all of these reasons we observed that the precision in the measured particle signals from $\mathrm{CO}^{+}, \mathrm{O}^{+}, \mathrm{OH}^{+}$and $\mathrm{H}_{2} \mathrm{O}^{+}$, were all much lower than precision in all other significant components of the spectra, including $\mathrm{CO}_{2}^{+}$. For this reason we calculated the particle phase signals at these fragments based on the measured particle $\mathrm{CO}_{2}^{+}$fragment, and the fragmentation table suggested by Aiken et al. (2008). Because of the relatively low signals at these fragments these choices had a minor effect on the calculated atomic ratios. For all of the standards except for the butane hydroxynitrate the O/C based on measured vs. calculated values of these fragments were within 5\%. For the butane hydroxynitrate standard the difference was larger, but only because the total aerosol concentration was much lower, and gas phase water therefore introduced much more noise into the measurement of $\mathrm{H}_{\mathrm{x}} \mathrm{O}^{+}$ fragments. Using the calculated fragments resulted in $\mathrm{O} / \mathrm{C}$ from the three measured spectra of this standard with precision $\pm 3 \%$. The AMS elemental ratios we report are those calculated before applying any corrections for reduced detection efficiency of $\mathrm{H}, \mathrm{N}$, or $\mathrm{O}$ relative to $\mathrm{C}$.

\subsection{Organic nitrate standards}

Polydisperse aerosols of each standard were generated by nebulizing a methanol solution of each standard with zero air using a Meinhard nebulizer (Meinhard Glass Products, Golden, CO). The resulting aerosol was passed through a silica gel diffusion dryer and multiple charcoal denuders to remove the solvent and excess gas phase organics before sampling into the HR-ToF-AMS. Pure samples of the methanol solvent sampled into the AMS in the same way resulted in 


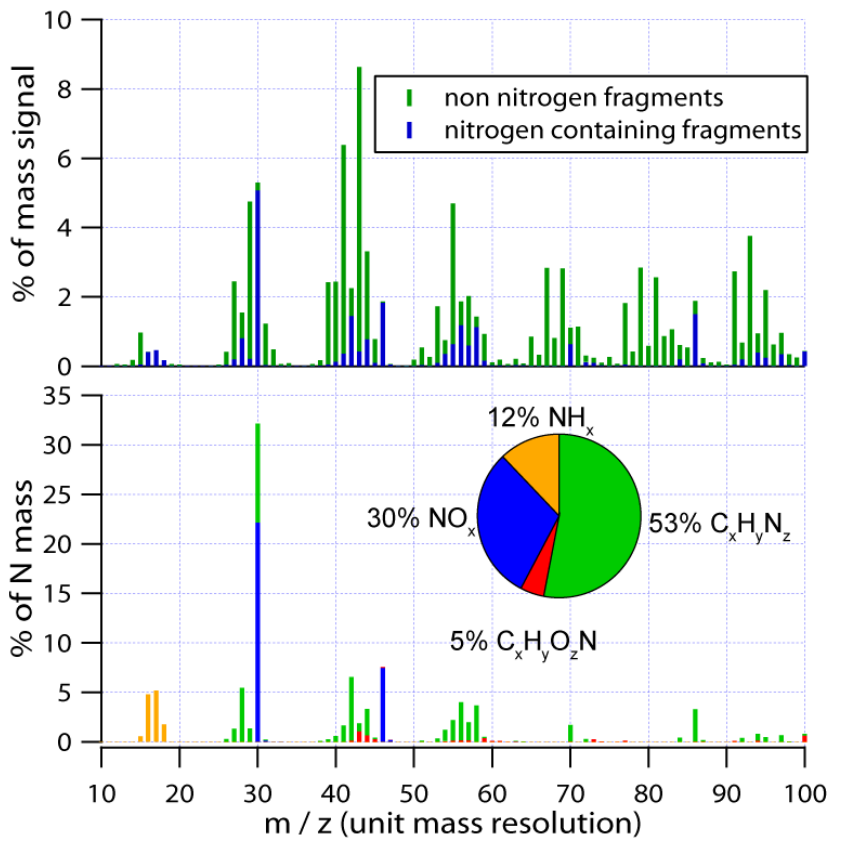

Fig. 2. Top: the average of the AMS spectra of the four standards, with nitrogen and non-nitrogen fragments identified. Numbers identify the $\mathrm{m} / \mathrm{z}$ of some of the major peaks. Bottom: the average for the standards of the nitrogen containing peaks, weighted by the fraction of each peak which is nitrogen by mass. Each peak containing one nitrogen atom is scaled by $\frac{14}{\mathrm{~m} / \mathrm{z}}$.

zero signal. Zero air produced from a zero air generator was chosen as opposed to e.g. argon gas to give a realistic AMS signal with the same interferences encountered in field measurements. 3-5 replicate spectra were recorded for each of the standards. Each spectrum was collected from $1 \mathrm{~min}$ of data and particle loadings were from $83-340 \mu \mathrm{g} \mathrm{m}^{-3}$. The precision for individual standards was high, with the precision of the resulting atomic ratios being $\pm 4 \%$. We report the averages of the spectra and atomic ratios.

\section{AMS organic nitrate spectrum}

Figure 2 (top panel) shows the average of the AMS spectra from the four standards. HR analysis was used to identify the peaks containing nitrogen (blue), and then the spectrum was summed to unit mass resolution. To focus on the organic nitrate functionality and compare the four compounds which had quite different carbon backbones, a subset of the spectrum of each standard was used where only the HR peaks containing nitrogen were identified and then scaled by the nitrogen content of each fragment (i.e. each fragment with one $\mathrm{N}$ atom was multiplied by $\frac{14}{\mathrm{~m} / \mathrm{z}}$ ), and then the spectra were summed to unit mass resolution. Figure 2 (bottom) shows the average nitrogen specta of the four standards obtained this way. The spectra of
Table 2. Contributions (\%) to the HR-AMS mass spectra of each of the standards (columns 1-4), and ratios of these peak heights (columns 5, 6). 30 and 46 are all of the signal at these UMR peaks. $\mathrm{NO}^{+}$and $\mathrm{NO}_{2}^{+}$are determined in the HR analysis. Stated AMS atomic ratios are without using correction factors for non-uniform detection of $\mathrm{C}, \mathrm{H}, \mathrm{N}$, and $\mathrm{O}$.

\begin{tabular}{lrrrrrr}
\hline Compound & 30 & 46 & $\mathrm{NO}^{+}$ & $\mathrm{NO}_{2}^{+}$ & $30: 46$ & $\mathrm{NO}^{+}: \mathrm{NO}_{2}^{+}$ \\
\hline Butane & 14.35 & 4.47 & 7.64 & 4.18 & 3.21 & 1.83 \\
Limonene & 3.37 & 2.23 & 2.07 & 2.09 & 1.51 & 0.99 \\
$\alpha$-Pinene & 2.96 & 0.58 & 2.65 & 0.50 & 5.10 & 5.30 \\
Caryophyllene & 2.01 & 0.45 & 1.79 & 0.40 & 4.47 & 4.48 \\
\hline
\end{tabular}

the individual compounds as well as many of the individual peak fits are contained in the supplementary material for this paper (see http://www.atmos-meas-tech.net/3/301/2010/ amt-3-301-2010-supplement.pdf). In comparison to ammonium nitrate where typically $>98 \%$ of the nitrate signal appears at the $\mathrm{NO}^{+}$and $\mathrm{NO}_{2}^{+}$peaks, we observed only $30 \%$ of the nitrogen at the sum of these two peaks. We observed 5\% at various $\mathrm{C}_{\mathrm{x}} \mathrm{H}_{\mathrm{y}} \mathrm{O}_{\mathrm{z}} \mathrm{N}^{+}$fragments, $12 \%$ in the $\mathrm{NH}_{\mathrm{x}}^{+}$fragments (mainly the butane standard) and $53 \%$ at various $\mathrm{C}_{\mathrm{x}} \mathrm{H}_{\mathrm{y}} \mathrm{N}^{+}$ fragments. The $\mathrm{NH}_{\mathrm{x}}^{+}$fragments were almost exclusively observed in the butane hydroxynitrate standard. We have no evidence that this is not unusual ion chemistry but acknowledge that these peaks may indicate an undetected impurity in the sample. The ubiquity of the $\mathrm{CHN}^{+}$fragments across the 4 standards was surprising and suggests a high degree of molecular rearrangement, not simple fragmentation, occurs prior to detection.

An attempt was made to identify a unique and consistent feature of the spectra which could be used to quantify the organic nitrate content of ambient OA using either a Unit Mass Resolution (UMR) - or High Resolution (HR) - AMS. Although qualitative similarities between the spectra of the four standards are obvious, no single peak was an unambiguous marker that could be used to quantify organic nitrates. Table 2 shows the observed $\mathrm{NO}^{+}: \mathrm{NO}_{2}^{+}$ratios observed for the four compounds. This ratio has been shown previously (Alfarra et al., 2006; Cottrell et al., 2008; Fry et al., 2009) to differ significantly between inorganic and organic nitrates. The $\mathrm{NO}^{+}: \mathrm{NO}_{2}^{+}$ratio has been shown to also vary between different instruments, and to change between tunings of a single instrument. Reported ranges for ammonium nitrate are typically $1.5-2.5 \mathrm{NO}^{+}: \mathrm{NO}_{2}^{+}$, with larger ratios observed for other compounds, ranging as high as 29 $\mathrm{NO}^{+}: \mathrm{NO}_{2}^{+}$for sodium nitrate. We observed ratios ranging from 0.99 to 5.30 for the organic nitrate standards. The average spectrum shown in Fig. 2 (bottom panel) has an $\mathrm{m} / \mathrm{z}$ 30:46 ratio of 2.94. This scatter in the $\mathrm{NO}: \mathrm{NO}_{2}$ ratios was unexpected as we anticipated that based on the gas phase decomposition of alkyl nitrates (Day et al., 2002) the majority of these compounds would thermally decompose to 
$\mathrm{RO}+\mathrm{NO}_{2}$ on the AMS filament, yielding essentially a mass spectrum of $\mathrm{NO}_{2}$. For example, at $600^{\circ} \mathrm{C}$ and 1 atm the lifetime of n-propyl nitrate in the gas phase to this thermal decomposition channel is $300 \mathrm{~ns}$.

None of the other major peaks were observed to bear a consistent relationship to the total $\mathrm{N}$ mass, or to either of the peaks at $\mathrm{m} / \mathrm{z} 30$ or 46 . One obvious feature in the spectrum is the clusters of mass around the groups $\mathrm{C}_{\mathrm{x}} \mathrm{H}_{\mathrm{y}} \mathrm{N}^{+}$, with the highest peak in each group occurring at $y=2 x(28,42,56$, 70 ). While this may be a unique signature of organic nitrates, the individual peaks are all small compared to the typical size of peaks at the same UMR $\mathrm{m} / \mathrm{z}$ in an ambient spectrum.

Assuming that the average of the four standards is representative of how particulate organic nitrates would appear in an AMS spectrum, we calculate that $58 \%$ of the nitrogen is measured at peaks other than the $\mathrm{NO}_{\mathrm{x}}^{+}$and $\mathrm{NH}_{\mathrm{x}}^{+}$. Using a HR-AMS to identify nitrogen containing fragments, if $M$ is the total amount of organic nitrogen measured at these non $\mathrm{NO}_{\mathrm{x}}^{+}$and $\mathrm{NH}_{\mathrm{x}}^{+}$peaks, then the total amount of organic nitrogen in all fragments would be $M / 0.58=1.7 \times M$, and the amount of organic nitrogen detected at the $\mathrm{NO}_{\mathrm{x}}^{+}$peaks would be $1.7 \times 0.30 \times M=0.51 \times M$.

\section{AMS/combustion comparison}

To evaluate the AMS's relative detection efficiency of $\mathrm{C}, \mathrm{H}$, $\mathrm{N}$, and $\mathrm{O}$ we compare the elemental ratios of the standards determined with the AMS to those measured with combustion analysis. The data are listed in Table 1 and plotted in Fig. 3. In Table 1 we also list the atomic ratios expected for pure samples of the standards. Assuming that the combustion analysis is the best measure of the composition of the compounds, this analysis indicates that the N/C and O/C of the synthetic standards are lower than expected. Though the standards were purified via flash chromatography, this suggests there was a carbon impurity in the standards, presumably from unreacted starting material or minor product(s) of the synthesis. The direct comparison of the two EA measurements may help to eliminate the need to assume a pure sample of the standard, though we expect that an impurity of lower vapor pressure than the standard would lead to more relative signal in the AMS than in the combustion method.

Correlation between AMS and thermal EA measurements is high for all three ratios $\left(R^{2}=0.988,0.966,1.000\right.$ for $\mathrm{H} / \mathrm{C}$, $\mathrm{N} / \mathrm{C}, \mathrm{O} / \mathrm{C}$ ). For $\mathrm{H} / \mathrm{C}$ and $\mathrm{N} / \mathrm{C}$ a negligible improvement in the linear regression was achieved by allowing the $y$-intercept to vary $\left(R^{2}=0.995\right.$ vs. 0.988 for $\mathrm{H} / \mathrm{C}$ and 0.978 vs. 0.966 for N/C). However for the O/C a reasonably significant improvement is observed (0.894 vs. 1.000$)$ by allowing the $y$ intercept to be non-zero. The positive $y$-intercept might indicate a positive bias in the AMS measurement of oxygen, possibly from a constant in the gas phase background. This would presumably appear as a large fraction of the total measured oxygen appearing at a nominally "air" $\mathrm{m} / \mathrm{z}$, such as
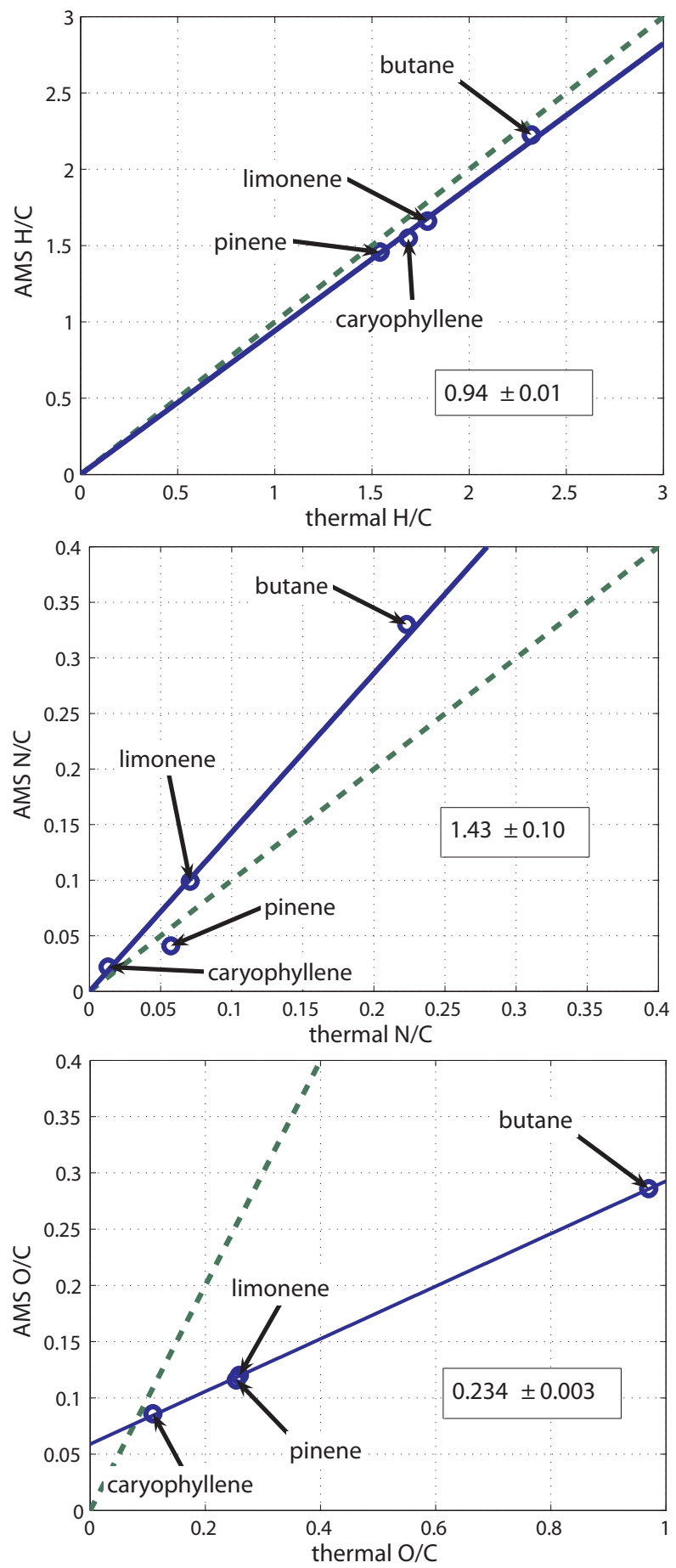

Fig. 3. Comparison of atomic ratios measured with the AMS, to atomic ratios measured by combustion elemental analysis. Here we plot the elemental ratios calculated assuming equal response to $\mathrm{CHN}$ and $\mathrm{O}$ (corrections to elemental analysis recommended by Aiken et al. (2008) have not been applied to the data). Green dashed line is a $1: 1$, and solid blue is a linear fit to the data. 
$\mathrm{O}^{+}, \mathrm{O}_{2}^{+}, \mathrm{CO}^{+}$or $\mathrm{CO}_{2}^{+}$. However, $\mathrm{O}_{2}^{+}$is filtered out in the analysis, and $\mathrm{O}^{+}$and $\mathrm{CO}^{+}$are calculated from the observed $\mathrm{CO}_{2}^{+}$signal which was overall a small fraction of the total measured oxygen. The deviation of the intercept from zero could also be explained by a negative bias in the detection of carbon. Because the AMS elemental analysis only considers fragments up to $m / z=100$, if a larger fraction of the total carbon relative to oxygen is contained in the excluded fragments greater than, $m / z=100$, then the AMS O/C would be systematically high. To consider the potential magnitude of this effect we calculated the mass weighted average $\mathrm{m} / \mathrm{z}$ for the observed $\mathrm{C}, \mathrm{H}, \mathrm{N}$, and $\mathrm{O}$ and results are listed in Table 3. Also listed in Table 3 is the fraction of total organic mass (calculated with unit mass resolution) located at $m / z \leq 100$. In general $\mathrm{O}$ and $\mathrm{N}$ are found at lower $m / z$ than are $\mathrm{C}$ and $\mathrm{H}$, and the fraction of total mass located at $m / z>100$ and therefore excluded from the elemental analysis increases monotonically with compound mass. These results suggest that in general if the majority of oxygen is always located at $m / z \leq 100$, larger compounds with more $\mathrm{C}$ excluded from the analysis will have an overestimated $\mathrm{O} / \mathrm{C}$ which increases with the size of the compound. To test the effect that this could have on our results we re-fit the AMS/thermal O/C comparison, making the assumption that all oxygen is detected below $\mathrm{m} / \mathrm{z}, 100$, and that the fraction of total carbon detected below $\mathrm{m} / z 100$ is equal to the fraction of OM observed below $m / z 100$ in the UMR analysis. Doing so brings the $y$-intercept of the O/C panel in Fig. 3 from 0.059 to 0.029, with the slope of the line only increasing slightly from 0.234 to 0.237 . Adjusting the carbon in this way also reduces the difference between the quality of fit found from allowing the $y$-intercept to vary $\left(R^{2}=0.999\right)$ and with $y$-intercept fixed at zero $\left(R^{2}=0.962\right)$. A similar analysis was performed on the N/C because Table 3 shows that nitrogen is found on average at even lower $\mathrm{m} / \mathrm{z}$ than is oxygen and yet no significant offset was found in the AMS/thermal N/C comparison. The correction due to excluded carbon above $\mathrm{m} / \mathrm{z} 100$ has a much less notable impact on the N/C, with the difference between fitting the $y$-intercept $\left(R^{2}=0.977\right)$ and fixing at zero $\left(R^{2}=0.946\right)$. This less significant effect is observed because the N/C for the largest compound is already very small, and shifting it slightly has a minor effect on the fit line.

$\mathrm{H} / \mathrm{C}$ measured for hydroxynitrates $(0.94 \pm 0.01)$ and by Aiken et al. (2008) for a range of other compounds $(0.91 \pm 0.02)$ are equivalent within the combined uncertainty. $\mathrm{N} / \mathrm{C}$ for hydroxynitrates was biased high $(1.4 \pm 0.1)$ as compared to the small negative bias previously observed for nitrogen containing organics $(0.96 \pm 0.05)$. Our observed $\mathrm{O} / \mathrm{C}$ ratio $(0.23 \pm 0.01)$ is significantly lower than that of Aiken et al. (2008) $(0.75 \pm 0.05)$. This pair of findings would seem to be reasonable considering that the nitrogen in these molecules was bonded to oxygen. Because oxygen is strongly electronegative and upon EI leaves preferentially as a neutral, the nitrogen is forced to preferentially leave as an ion.
Table 3. Mass weighted average location of $\mathrm{C}, \mathrm{H}, \mathrm{N}$, and $\mathrm{O}$ calculated by high resolution AMS analysis of $m / z \leq 100$ (first four columns) and the percent of organic mass located $\leq m / z, 100$ evaluated by unit mass resolution up to $m / z=500$. Correction factors for non-uniform detection of $\mathrm{C}, \mathrm{H}, \mathrm{N}$, and $\mathrm{O}$ have not been applied to the data.

\begin{tabular}{lrrrrr}
\hline Compound & $\mathrm{C}$ & $\mathrm{H}$ & $\mathrm{N}$ & $\mathrm{O}$ & $\%$ \\
\hline Butane & 51.1 & 47.2 & 36.0 & 40.1 & 91 \\
Pinene & 62.3 & 59.4 & 40.1 & 49.0 & 74 \\
Limonene & 60.4 & 58.0 & 44.5 & 50.0 & 74 \\
Caryophyllene & 64.7 & 62.1 & 42.5 & 51.4 & 69 \\
\hline
\end{tabular}

The origin of the nonzero $y$-intercept in the comparison of AMS and combustion measurements of $\mathrm{O} / \mathrm{C}$ is not entirely clear, and as discussed is likely related to the size of the carbon backbone of the parent molecule. Thus, to make an estimate of how the $\mathrm{O} / \mathrm{C}$ of organic nitrates may appear for ambient aerosol we take the average of the AMS O/C/ combustion $\mathrm{O} / \mathrm{C}$ for the four compounds. The average of this value for the four compounds (Table 1, bottom line) is 0.50 , which is close to the individual values observed for the two monoterpene derived compounds ( 0.46 and 0.46$)$. The four compounds tested in this study were nominally composed of one alcohol group (R-O-H) and one alkyl nitrate group (R-O$\mathrm{NO}_{2}$ ) with a total of 4 oxygen atoms per molecule. We estimate the reduced detection efficiency of oxygen in the organic nitrate groups alone by assuming that the oxygen in the alcohol groups were detected with $75 \%$ efficiency (Aiken et al., 2008), and the reduced detection efficiency of $\mathrm{O}$ in nitrates lead to the overall observed value of 0.50 . Under these assumptions, the detection efficiency for oxygen in a nitrate group is $42 \%$.

\section{Impact on ambient OA observations}

In this section we estimate how the reduced efficiency of oxygen detection in organic nitrates might affect observations of $\mathrm{O} / \mathrm{C}$ using the HR-ToF-AMS EA technique in the extreme case that all detected nitrogen is from organic nitrates. Under this assumption, we use our results from Sects. 3 and 4 to calculate that the $\mathrm{O} / \mathrm{C}$ and N/C ratios reported using standard assumptions about AMS spectra and the calibration factors determined in Aiken et al. (2008) is related to the true O/C ratio by:

$$
\left(\frac{\mathrm{O}}{\mathrm{C}}\right)_{\text {true }}=\left(\frac{\mathrm{O}}{\mathrm{C}}\right)_{\text {rep }}+1.5\left(\frac{\mathrm{N}}{\mathrm{C}}\right)_{\text {rep }}
$$

such that the fractional adjustment to the reported $\mathrm{O} / \mathrm{C}$ ratio would be $150 \frac{\mathrm{N} / \mathrm{C}}{\mathrm{O} / \mathrm{C}} \%$. Here, "true" refers to atomic ratios existing in atmospheric aerosols, "observed" (obs) ratios are those one measures with the raw AMS data without any corrections for relative biases between atoms, and "reported" 
Table 4. A summary of the conversion factors used in deriving Eq. (1).

\begin{tabular}{|c|c|c|}
\hline Value & Description of value & Reference \\
\hline 0.42 & observed $\mathrm{O}: \mathrm{C} /$ true $\mathrm{O}: \mathrm{C}$ for organic nitrates & this study, Sect. 4 \\
\hline 0.75 & observed $\mathrm{O}: \mathrm{C} /$ true $\mathrm{O}: \mathrm{C}$ for all organics & Aiken et al. (2008) \\
\hline 1.4 & observed $\mathrm{N}: \mathrm{C}$ / true $\mathrm{N}: \mathrm{C}$ for organic nitrates & this study, Sect. 4 \\
\hline 0.96 & observed $\mathrm{N}: \mathrm{C} /$ true $\mathrm{N}: \mathrm{C}$ for all organics & Aiken et al. (2008) \\
\hline 1.7 & organic $\mathrm{N}$ in all fragments / organic $\mathrm{N}$ in "organic" fragments & this study, Sect. 3 \\
\hline
\end{tabular}

(rep) ratios are those one finds in the literature (e.g. Aiken et al., 2008) using previously determined correction factors.

In the following we derive Eq. 1 using the various relationships between measured and true $\mathrm{O} / \mathrm{C}$ and N/C ratios reported in this study, and that of Aiken et al. (2008). These values are summarized in Table 4 . First we consider the differences in $\mathrm{O} / \mathrm{C}$ between the two studies. We assume that the oxygen in organic nitrate groups is detected with $42 \%$ efficiency, and all other organic oxygen at $75 \%$ efficiency. Since each nitrate group has 3 oxygen atoms, the contribution to the observed $\mathrm{O} / \mathrm{C}$ from nitrates is $0.42 \times 3\left(\frac{\mathrm{N}}{\mathrm{C}}\right)$ true and the contribution from the other (non-nitrate) oxygen containing organics is $0.75 \times\left[\left(\frac{\mathrm{O}}{\mathrm{C}}\right)_{\text {true }}-3\left(\frac{\mathrm{N}}{\mathrm{C}}\right)_{\text {true }}\right]$. Thus the true $\mathrm{O} / \mathrm{C}$ is related to the observed $\mathrm{O} / \mathrm{C}$ by the sum of the these two contributions, which can be rearranged to yield the following expression:

$$
\left(\frac{\mathrm{O}}{\mathrm{C}}\right)_{\text {true }}=\frac{\left(\frac{\mathrm{O}}{\mathrm{C}}\right)_{\mathrm{obs}}+0.99\left(\frac{\mathrm{N}}{\mathrm{C}}\right)_{\text {true }}}{0.75}=\frac{\left(\frac{\mathrm{O}}{\mathrm{C}}\right)_{\mathrm{obs}}}{0.75}+1.3\left(\frac{\mathrm{N}}{\mathrm{C}}\right)_{\text {true }}
$$

Since the factor 0.75 has been used in the literature to report $\mathrm{O} / \mathrm{C}$ values, we have:

$$
\left(\frac{\mathrm{O}}{\mathrm{C}}\right)_{\text {reported }}=\frac{\left(\frac{\mathrm{O}}{\mathrm{C}}\right)_{\mathrm{obs}}}{0.75}
$$

We assume that the reported and observed N/C ratios are related by $\left(\frac{N}{\mathrm{C}}\right)_{\text {rep }} \times 0.96=\left(\frac{\mathrm{N}}{\mathrm{C}}\right)_{\text {obs }}$ and as we have seen, for organic nitrates $\left(\frac{\mathrm{N}}{\mathrm{C}}\right)_{\text {true }}=\left(\frac{\mathrm{N}}{\mathrm{C}}\right)_{\text {obs }} / 1.4$. Typically however, elemental analysis is applied to the "organic" part of the AMS spectrum which is determined as such through standard assumptions about the spectrum (Allan et al., 2004) followed by the application of a multivariate linear regression technique such as positive matrix factorization which essentially removes all signal at the $\mathrm{NO}_{\mathrm{x}}^{+}$and $\mathrm{NH}_{\mathrm{x}}^{+}$peaks (Zhang et al., 2005; Lanz et al., 2007, 2008). To account for organic $\mathrm{N}$ in these peaks the reported $\mathrm{N} / \mathrm{C}$ should be scaled up by a factor of 1.7 as discussed in Sect. 3, resulting in the relationship

$$
\left(\frac{\mathrm{N}}{\mathrm{C}}\right)_{\text {true }}=\frac{\left(\frac{\mathrm{N}}{\mathrm{C}}\right)_{\mathrm{rep}} \times 0.96}{1.4} \times 1.7
$$

Combining Eqs. (3) and (4) with Eq. (2) we arrive at Eq. (1).
Applying Eq. (1) to the diurnal average N/C and O/C ratios observed by Aiken et al. (2008) in Mexico City (MILAGRO campaign) we obtain an average increase in the $\mathrm{O} / \mathrm{C}$ ratio of $8.6 \%$. Ambient $\mathrm{N} / \mathrm{C}$ and $\mathrm{O} / \mathrm{C}$ ratios however are anticorrelated. Thus, the while the $\mathrm{O} / \mathrm{C}$ ratio observed by Aiken et al. (2008) ranges from $0.31-0.55$, the $\mathrm{N} / \mathrm{C}$ ratio ranges from 0.024-0.009 (approx, read from charts). This suggests that the organic nitrate correction to OA oxygen content for this study would vary from $2-12 \%$, being the most important just before sunrise, and least important late in the day.

The results of the above analysis rely on the critical assumption that all observed $\mathrm{N}$ in the organic spectrum is from organic nitrates. This is however unlikely to be the case, meaning that the $2-12 \%$ correction we calculate to the $\mathrm{O} / \mathrm{C}$ is an upper limit. For example, Moffet et al. (2008) report single particle mass spectrometric measurements during the Mexico City Metropolitan Area-2006 campaign (MCMA2006) and find a significant class of nitrogen containing organic particles which they hypothesize to be due to industrial emissions of amines. Aiken et al. (2009) report PMF analysis of HR-AMS data from this same campaign, and find a component high in organic nitrogen (called LOA in that study) which they suggest is likely of similar origin. It is worth noting though that in the study of Aiken et al. (2009) only 33\% of the organic nitrogen was found in the LOA component, with the OOA, HOA and BBOA having 29\%, 25\% and $13 \%$ each, respectively. As well, one of the pieces of reasoning used to conclude that the nitrogen is from amines is that it is detected in $\mathrm{C}_{\mathrm{x}} \mathrm{H}_{\mathrm{y}} \mathrm{N}^{+}$fragments, such as $m / z 58$ (Moffet et al., 2008) and $m / z 86$ (Huffman et al., 2009) which are observed in mass spectroscopic studies of amines. Our observations of significant quantities of $\mathrm{C}_{\mathrm{x}} \mathrm{H}_{\mathrm{y}} \mathrm{N}^{+}$fragments from organic nitrates including in particular $\mathrm{m} / \mathrm{z} 58$ and 86 suggests that these fragments may not be perfect tracers for amines. Finally, we note that the range of possible corrections calculated in this paper are well within the stated $31 \%$ accuracy (Aiken et al., 2008) of the AMS EA technique.

\section{Conclusions}

We have tested the response of the Aerodyne HR-TOF-AMS to aerosols formed from $\mathrm{C}_{4}-\mathrm{C}_{15}$ hydroxynitrates. We found on average that $42 \%$ of the nitrogen mass was detected at the 
$\mathrm{NO}_{\mathrm{x}}^{+}$and $\mathrm{NH}_{\mathrm{x}}^{+}$peaks, which are typically assumed to be inorganic nitrogen. We find that the oxygen in these molecules was detected with significantly reduced efficiency $(50 \%$ on average) as compared to a previously reported series of organics $(75 \%)$. This could result in as much as an $12 \%$ increase in the $\mathrm{O} / \mathrm{C}$ ratio previously reported for Mexico City where the observed N/C was high. Analysis of the mass spectrum did not yield any patterns which could be used universally to quantify the organic nitrate content of aerosol, but suggests that $58 \%$ of the $\mathrm{N}$ is detected at $\mathrm{CHN}^{+}$and $\mathrm{CHNO}^{+}$ fragments.

Acknowledgements. The Berkeley authors were supported by NSF ATM-0639847 and NSF ATM-0511829. The authors would like to thank M. Spittler for suggestions regarding the synthetic chemistry, and to M. Motamed and S. House in the research group of R. Sarpong for assistance and facilities for performing synthesis. $\mathrm{K}$. Wilson and J. Smith are thanked as well for their assistance with the AMS experiments. Discussions with D. Farmer and J. Jimenez regarding the data analysis were also very appreciated.

Edited by: A. J. M. Piters

\section{References}

Aiken, A., DeCarlo, P., and Jimenez, J.: Elemental analysis of organic species with electron ionization high-resolution mass spectrometry, Anal. Chem., 79, 8350-8358, 2007.

Aiken, A. C., DeCarlo, P. F., Kroll, J. H., Worsnop, D. R., Huffman, J. A., Docherty, K. S., Ulbrich, I. M., Mohr, C., Kimmel, J. R., Sueper, D., Sun, Y., Zhang, Q., Trimborn, A., Northway, M., Ziemann, P. J., Canagaratna, M. R., Onasch, T. B., Alfarra, M. R., Prevot, A. S. H., Dommen, J., Duplissy, J., Metzger, A., Baltensperger, U., and Jimenez, J. L.: O/C and OM/OC ratios of primary, secondary, and ambient organic aerosols with high-resolution time-of-flight aerosol mass spectrometry, Environ. Sci. Technol., 42, 4478-4485, 2008.

Aiken, A. C., Salcedo, D., Cubison, M. J., Huffman, J. A., DeCarlo, P. F., Ulbrich, I. M., Docherty, K. S., Sueper, D., Kimmel, J. R., Worsnop, D. R., Trimborn, A., Northway, M., Stone, E. A., Schauer, J. J., Volkamer, R. M., Fortner, E., de Foy, B., Wang, J., Laskin, A., Shutthanandan, V., Zheng, J., Zhang, R., Gaffney, J., Marley, N. A., Paredes-Miranda, G., Arnott, W. P., Molina, L. T., Sosa, G., and Jimenez, J. L.: Mexico City aerosol analysis during MILAGRO using high resolution aerosol mass spectrometry at the urban supersite (T0) - Part 1: Fine particle composition and organic source apportionment, Atmos. Chem. Phys., 9, 66336653, 2009,

http://www.atmos-chem-phys.net/9/6633/2009/.

Alfarra, M. R.: Insights Into Atmospheric Organic Aerosols Using An Aerosol Mass Spectrometer, Ph.D. Thesis, University of Manchester, 2004.

Alfarra, M. R., Paulsen, D., Gysel, M., Garforth, A. A., Dommen, J., Prévôt, A. S. H., Worsnop, D. R., Baltensperger, U., and Coe, H.: A mass spectrometric study of secondary organic aerosols formed from the photooxidation of anthropogenic and biogenic precursors in a reaction chamber, Atmos. Chem. Phys.,
6, 5279-5293, 2006,

http://www.atmos-chem-phys.net/6/5279/2006/.

Allan, J., Delia, A., Coe, H., Bower, K., Alfarra, M., Jimenez, J., Middlebrook, A., Drewnick, F., Onasch, T., Canagaratna, M., Jayne, J., and Worsnop, D.: A Generalised method for the extraction of chemically resolved mass spectra from aerodyne aerosol mass spectrometer data, J. Aerosol Sci., 35, 909-922, 2004.

Arey, J., Aschermann, S. M., Kwok, E. S. C., and Atkinson, R.: Alkyl Nitrate, Hydroxyalkyl Nitrate, and Hydroxycarbonyl Formation from the $\mathrm{NO}_{\mathrm{x}}$-Air Photooxidations of $\mathrm{C}_{5}-\mathrm{C}_{8} n$-Alkanes, J. Phys. Chem. A., 105, 1020-1027, 2001.

Canagartna, M., Jayne, J., Jimenez, J., Allan, J., Alfarra, M., Zhang, Q., Onaxch, T., Drewnick, F., Coe, H., Middlebrook, A., Delia, A., Williams, L., Trimborn, A., Northway, M., DeCarlo, P., Kolb, C., Davidovits, P., and Worsnop, D.: Chemical and microphysical characteriation of ambient aerosols with the aerodyne aerosol mass spectrometer, Mass Spectrom. Rev., 26, 185-222, 2007.

Cottrell, L. D., Griffin, R. J., Jimenez, J. L., Zhang, Q., Ulbrich, I., Ziemba, L. D., Beckman, P. J., Sive, C. B., and Talbot, R. W.: Submicron particles at Thompson Farm during ICARTT measured using aerosol mass spectrometry, J. Geophys. Res., 113, D08212, doi:10.1029/2007JD009192, 2008.

Day, D. A., Wooldridge, P. J., Dillon, M., Thornton, J. A., and Cohen, R. C.: A thermal dissociation laser-induced fluorescence instrument for in situ detection of $\mathrm{NO}_{2}$, peroxy nitrates, alkyl nitrates, and $\mathrm{HNO}_{3}$, J. Geophys. Res., 107(D6), 4046, doi:10.1029/2001JD000779, 2002.

DeCarlo, P. F., Kimmel, J. R., Trimborn, A., Northway, M. J., Jayne, J. T., Aiken, A. C., Gonin, M., Fuhrer, K., Horvath, T., Docherty, K. S., Worsnop, D. R., and Jimenez, J. L.: Fielddeployable, high-resolution, time-of-flight aerosol mass spectrometer, Anal. Chem., 78, 8281-8289, 2006.

Dzepina, K., Arey, J., Marr, L. C., Worsnop, D. R., Salcedo, D., Zhang, Q., Onasch, T. B., Molina, L. T., Molina, M. J., and Jimenez, J. L.: Detection of particle-phase polycyclic aeromatic hydrocarbons in Mexico City using and aerosol mass spectrometer, Int. J. Mass. Spectrom., 263, 152-170, 2007.

Fry, J. L., Kiendler-Scharr, A., Rollins, A. W., Wooldridge, P. J., Brown, S. S., Fuchs, H., Dubé, W., Mensah, A., dal Maso, M., Tillmann, R., Dorn, H.-P., Brauers, T., and Cohen, R. C.: Organic nitrate and secondary organic aerosol yield from $\mathrm{NO}_{3}$ oxidation of $\beta$-pinene evaluated using a gas-phase kinetics/aerosol partitioning model, Atmos. Chem. Phys., 9, 1431-1449, 2009, http://www.atmos-chem-phys.net/9/1431/2009/.

Gómez-Gonzaález, Y., Surratt, J. D., Ceyckens, F., Szmigielski, R., Vermeylen, R., Jaoui, M., Lewandowski, M., Offenberg, J. H., Kleindienst, T. E., Edney, E. O., Blockhuys, F., Alsenoy, C. V., Maenhaut, W., and Claeys, M.: Characterization of organosulfates from the photooxidation of isoprene and unsaturated fatty acids in ambient aerosol using liquid chromatography/(-)electrospray ionization mass spectrometry, J. Mass. Spec., 43, 371-382, 2008.

Hoffmann, T., Odum, J. R., Bowman, F., Collins, D., Klockow, D., Flagan, R. C., and Seinfeld, J. H.: Formation of organic aerosols from the oxidation of biogenic hydrocarbons, J. Atmos. Chem., 26, 189-222, doi:10.1023/A:1005734301837, 1997. 
Huffman, J. A., Docherty, K. S., Aiken, A. C., Cubison, M. J., Ulbrich, I. M., DeCarlo, P. F., Sueper, D., Jayne, J. T., Worsnop, D. R., Ziemann, P. J., and Jimenez, J. L.: Chemically-resolved aerosol volatility measurements from two megacity field studies, Atmos. Chem. Phys., 9, 7161-7182, 2009, http://www.atmos-chem-phys.net/9/7161/2009/.

Jimenez, J. L., Jayne, J. T., Shi, Q., Kolb, C. E., Worsnop, D. R., Yourshaw, I., Seinfeld, J. H., Flagan, R. C., Zhang, X., Smith, K. A., Morris, J. W., and Davidovits, P.: Ambient aerosol sampling using the Aerodyne Aerosol Mass Spectrometer, J. Geophys. Res., 108(D7), 8425, doi:10.1029/2001JD001213, 2003.

Kroll, J. H. and Seinfeld, J. H.: Chemistry of secondary organic aerosol: Formation and evolution of low-volatility organics in the atmosphere, Atmos. Environ., 42, 3593-3624, 2008.

Lanz, V. A., Alfarra, M. R., Baltensperger, U., Buchmann, B., Hueglin, C., and Prévôt, A. S. H.: Source apportionment of submicron organic aerosols at an urban site by factor analytical modelling of aerosol mass spectra, Atmos. Chem. Phys., 7, 15031522,2007 http://www.atmos-chem-phys.net/7/1503/2007/.

Lanz, V. A., Alfarra, M. R., Baltensperger, U., Buchmann, B., Hueglin, C., Szidat, S., Wehreli, M. N., Wacker, L., Weimer, S., Caseiro, A., Puxbaum, H., and Prévôt, A. S. H.: Source attribution of submicron organic aerosols during wintertime inversions by advanced factor analysis of aerosol mass spectra, Environ. Sci. Technol., 42, 214-220, 2008.

Moffet, R. C., de Foy, B., Molina, L. T., Molina, M. J., and Prather, K. A.: Measurement of ambient aerosols in northern Mexico City by single particle mass spectrometry, Atmos. Chem. Phys., 8, 4499-4516, 2008, http://www.atmos-chem-phys.net/8/4499/2008/.

Muthuramu, K., Shepson, P. B., and O'Brien, J. M.: Preparation, analysis, and atmospheric production of multifunctional organic nitrates, Environ. Sci. Technol., 27, 1117-1124, doi: 10.1021/es00043a010, 1993.

Ng, N. L., Kwan, A. J., Surratt, J. D., Chan, A. W. H., Chhabra, P. S., Sorooshian, A., Pye, H. O. T., Crounse, J. D., Wennberg, P. O., Flagan, R. C., and Seinfeld, J. H.: Secondary organic aerosol (SOA) formation from reaction of isoprene with nitrate radicals (NO3), Atmos. Chem. Phys., 8, 4117-4140, 2008, http://www.atmos-chem-phys.net/8/4117/2008/.
Nichols, P. L. J., Magnusson, A. B., and Ingham, J. D.: Synthesis of nitric esters by the addition of nitric acid to the ethylene oxide ring, J. Am. Chem. Soc., 75, 4255-4258, 1953.

Noziére, B., Barnes, I., and Becker, K.-H.: Product study and mechanisms of the reactions of $\alpha$-pinene and of pinonaldehyde with OH radicals, J. Geophys. Res., 104, 23645-23656, 1999.

Pankow, J. F. and Asher, W. E.: SIMPOL.1: a simple group contribution method for predicting vapor pressures and enthalpies of vaporization of multifunctional organic compounds, Atmos. Chem. Phys., 8, 2773-2796, 2008, http://www.atmos-chem-phys.net/8/2773/2008/.

Paulot, F., Crounse, J. D., Kjaergaard, H. G., Kroll, J. H., Seinfeld, J. H., and Wennberg, P. O.: Isoprene photooxidation: new insights into the production of acids and organic nitrates, Atmos. Chem. Phys., 9, 1479-1501, 2009, http://www.atmos-chem-phys.net/9/1479/2009/.

Rollins, A. W., Kiendler-Scharr, A., Fry, J. L., Brauers, T., Brown, S. S., Dorn, H.-P., Dubé, W. P., Fuchs, H., Mensah, A., Mentel, T. F., Rohrer, F., Tillmann, R., Wegener, R., Wooldridge, P. J., and Cohen, R. C.: Isoprene oxidation by nitrate radical: alkyl nitrate and secondary organic aerosol yields, Atmos. Chem. Phys., 9, 6685-6703, 2009, http://www.atmos-chem-phys.net/9/6685/2009/.

Spittler, M.: Untersuchungen zur troposphärischen Oxidation von Limonen: Produktanalysen, Aerosolbildung und Photolyse von Produkten, Ph.D. Thesis, Department of Physical Chemistry, University of Wuppertal, 2001.

Surratt, J. D., Murphy, S. M., Kroll, J. H., Ng, N. L., Hildebrandt, L., Sorooshian, A., Szmigielski, R., Vermeylen, R., Maenhaut, W., Clayes, M., Flagan, R. C., and Seinfeld, J. H.: Chemical Composition of Secondary Organic Aerosol Formed from the Photooxidation of Isoprene, J. Phys. Chem. A, 110, 9665-9690, 2006.

Treves, K. and Rudich, Y.: The atmospheric fate of $\mathrm{C}_{3}-\mathrm{C}_{6}$ hydroxyalkyl nitrates, J. Phys. Chem. A, 107, 7809-7817, 2003.

Treves, K., Shragina, L., and Rudich, Y.: Henry's law constants of some $\beta-, \gamma$-, and $\delta$-hydroxy alkyl nitrates of atmospheric interest, Environ. Sci. Technol., 34, 1197-1203, 2000.

Zhang, Q., Alfarra, M. R., Worsnop, D. R., Allan, J. D., Coe, H., Canagaratna, M. R., and Jimenez, J. L.: Deconvolution and quantification of hydrocarbon-line and oxygenated organic aerosols based on aerosol mass spectrometry, Environ. Sci. Technol., 39, 4938-4952, 2005. 